\title{
Improving the Students' Listening Comprehension through Drill Technique
}

\author{
Wirathama Hazera Putra \\ www.hazera@yahoo.co.id \\ Universitas Lampung
}

\begin{abstract}
This research was aimed at: 1) analyzing the improvement of the students' listening comprehension through drill technique, 2) finding out the problems the students face in learning micro skills of listening comprehension through drill technique. The data were obtained from the pre-test and post-test to analyze the improvement of the students' listening comprehension through drill technique, and also from the observation and interview to find out the problems the students face in learning micro skills of listening comprehension through drill technique. The result showed that the students' mean score of the pre-test was 52.2 and their mean score of the post-test after being taught through drill technique was 78.5, in which their gain score was 26.3. Specifically, drill technique improved the students' listening comprehension in all aspects of micro skill types of listening comprehension, such as recognition intonation pattern, recognition sentence pattern, recognition discourse marker, and getting the referential info. Moreover, drill technique mostly improved the students' listening comprehension in recognizing intonation pattern, in which their ability in that aspect was $38 \%$ improved significantly. Besides that, in line with what had been observed during the treatment, the problems the students faced in learning micro skills of listening comprehension through drill technique could be divided into: a) Problems from the listener, in example: understanding the difficult words/phrases, recognizing phonetic symbols and intonation pattern, distinguishing sentence pattern and discourse marker, and unable to keep up with the native speaker's speed; b) Problem from listening materials, in example some dialogues were long. However, after practicing the dialogues more frequently through drill technique, the students gradually started to comprehend the materials and were able to overcome those problems. Based on the results above, it could be concluded that: 1) drill technique could improve the students' listening comprehension better and significantly, especially in recognizing intonation pattern, 2) drill technique could overcome the problems the students faced during the treatment of teaching listening through drill technique.
\end{abstract}

Key Words: Drill technique, listening comprehension

\section{Introduction}

Learning English cannot be separated from learning the four main of language skills, such as listening, speaking, reading, and writing. Thus, the four aspects of language skills are integrated one another which the students have learnt from elementary level, up to senior high school level. From the four aspects of language skills, according to Griffee (1986), listening can be considered as the first step in learning a language. Besides that, according to Fisher and Terry (1980:138), listening is the first step of learning English. Moreover, listening as one of the aspects of language skills, according to McIntosh (1979:65), is one of the most important and fundamental of the four skills in language learning because listening gives the students information from which to complete the learners' knowledge in using English.

In learning English, according to Krashen (1985), there are two processes called input which consists of listening and reading; and output which consists of speaking and writing. Listening input is all that is necessary to language acquisition. So long as the learner receives comprehensible input, he or she will automatically become competent in the target language. The learners learn the target language by understanding messages first by receiving comprehensible input first, before producing the output. Therefore, listening is an important aspect of learning and it should be introduced as early as possible to develop the students' listening comprehension in learning English; for example, by giving the students, as the beginners, lots of listening practice before asking them to speak is more beneficial than getting them to speak from the very first stage. By listening, the students will get the information as their first input for their knowledge, then start to produce words or sentences by speaking as the first output, learn to read as the second input and start to write as the second output and the advanced level. Listening as the input and speaking as the output are related each other; moreover, according to Alexander (1967), nothing should be spoken before it has been heard.

However, it was found that the students of junior or senior high school got difficulties to participate in the process of English teaching learning activity. Moreover, related to the previous research which was conducted by 
Apriani (2012), it was found that, in the teaching-learning process, the students had difficulty in recognizing intonation pattern, sentence pattern, discourse marker, and getting the referential info. She found that most students only understood about half of what they listened, then after having ALM treatment three times, they retained less than twenty-five percent of comprehending the original message. As stated in Finocchiaro (1967:55), at the first time, the students seriously conflict with the production of the new language sounds because they do not immediately decode the sounds.

Even more, since listening skill affects the speaking skill, the students could not follow what their teacher was talking about. They were unable to speak English fluently because they lacked of listening skill. It seems the teaching learning method in the class preferred to use GTM (Grammar Translation Method) which did not frequently practice listening and was more concerned to grammatical structures for focusing on passing the national examination (UN). Thus, the students did not get much time to practice listening comprehension. As a result, they lacked of listening comprehension and often did not understand what the teacher said in English language.

Based on the facts that the students lacked of listening comprehension, the researcher is intended to use Audio Lingual Method (ALM) to improve the students' listening comprehension, especially in improving the students' micro skills of listening comprehension. ALM assumes that language learning is a process of habit formation. Since ALM focuses on listening and speaking ability, thus, listening and speaking come first, and reading and writing come later. Drill techniques such as repetition drill, substitution drill, transformation drill, replacement drill, response drill, cued response drill, rejoinder drill, restatement drill, completion drill, expansion drill, contraction drill, and integration drill are used in the form of target language dialogue. By drilling the students, it will be easier for them to remember and learn; since the more often English is repeated, the stronger the habit and the greater learning will be achieved. As in the process of a child for example, who learns his/her mother tongue, a child always begins with hearing first what his/her parents speak, then he/she tries to speak afterward. Thus, ALM believes that learning a foreign language is the same as the acquisition of the native language (Larsen-Freeman, 2000:43).

Therefore, based on the explanation above, this research was conducted in the $1^{\text {st }}$ grade students of SMPN 2 Bandar Lampung in order not only to improve their listening comprehension, but also to analyze the improvement of their listening comprehension through drill technique and to find out the problems the students face in learning micro skills of listening comprehension through drill technique.

\section{Method}

This research was a quantitative study which used one group pretest-posttest design. There was one class as the subject of the research which was chosen purposively. The research design was as follows:

\section{T1 X T2}

T1: Pre-test.

$\mathrm{X}$ : Treatment.

T2: Post-test.

(Setiyadi, 2006:133).

The experimental class was given the treatment of teaching listening comprehension through drill technique. The pre-test was administrated before the treatment of teaching listening comprehension through drill technique was implemented, to see the students' basic listening comprehension. Then, the treatment of teaching listening comprehension through drill technique was implemented. The post-test was administrated afterward, to analyze the improvement of the students' listening comprehension through drill technique.

The observation and the interview were also conducted in this research. The observation was conducted to observe the teaching-learning process during the treatment of teaching listening comprehension through drill technique. The interview was conducted in the form of open questions and formal types. It was conducted toward some representatives of the students as the interviewees, which were chosen from low and high scores based on the mean score of the post-test, to find out the problems the students face in learning micro skills of listening comprehension through drill technique, in which their answers were classified and generalized as the resource.

\section{Discussion}

The result of the research showed that the students' listening comprehension was improved after being taught through drill technique in 7 RSBI 2 class of SMPN 2 Bandar Lampung. The students' mean score after being 
taught through drill technique was increased better and significantly. The students' mean score of the pre-test was 52.2; meanwhile, their mean score of the post-test after being taught through drill technique was 78.5, in which their gain score was 26.3. Based on the finding, it can be seen from the students' mean score of the pre-test and post-test that there was a significant improvement before and after being taught through drill technique. Specifically, drill technique improved the students' listening comprehension in all aspects of micro skill types of listening comprehension, such as recognition intonation pattern, recognition sentence pattern, recognition discourse marker and getting the referential info. Moreover, drill technique mostly improved the students' listening comprehension in recognizing intonation pattern, in which their ability in that aspect was $38 \%$ improved significantly.

ALM believes that learning a foreign language is the same as the acquisition of the native language (LarsenFreeman, 2000:43), in the process of a child for example, who learns his/her mother tongue, a child always begins with hearing first what his/her parents speak, then he/she tries to speak afterward. Besides that, ALM assumes that language learning is a process of habit formation. It has its origins in B.F. Skinner's Verbal Behavior (1959) cited in Yufrizal (2007:43) that language is not mental phenomenon, but it is behavior, which like other forms of human behavior, it is learned by a process of habit formation. To the behaviorist, the human being is an organism capable of wide repertoire of behaviors. The occurrence of these behaviors is dependent on three crucial elements in learning, such as a stimulus, which serves to elicit behavior; a response which serves to mark the response as being appropriate, and reinforcement (encourages the repetition) which is a vital element in the learning process since it increases the likelihood that the behavior will occur again and become a habit (Skinner, 1957 in Brown, 1980). In teaching-learning process, the behavior is as verbal behavior, the stimulus as what is taught or presented of the foreign language, the response is as the learner's reaction to the stimulus, and the reinforcement is as the extrinsic approval and praise of the teacher or fellow students or the intrinsic self-satisfaction of target language use. Thus, language mastery is represented as acquiring language stimulus-response chains.

Moreover, ALM demands more memorization of structure-based dialogs. The students memorize an opening dialog using mimicry and applied role-playing. By listening, the students are expected to be able to mimic the model. In order to develop the students' listening comprehension in learning English, the students, as the beginners, are given lots of listening practice before asking them to speak is more beneficial than getting them to speak from the very first stage. For supporting more practice in listening, by using drill technique, the students practice listening and speaking more through the dialogues, then drill it in language games or role-play, in which the dialogues are memorized by reversing roles between teacher-student or student-student.

Based on the explanation above, it can be concluded that, learning English as a process of habit formation as the acquisition of the native language, by having lots of listening practice using drill technique through the dialogue, then drill it and memorize it by reversing roles between teacher-student or student-student in language games or role-play; improved not only the students' listening comprehension, but also their ability in memorizing. By drilling English as a process of habit formation, it will be easier for the students to remember and learn in listening practice, since they not only could comprehend the dialogues correctly by memorizing the dialogues they heard which can strengthen the students' memory, but also they could copy the native speaker voice to spell some difficult words correctly. Since the more often English is repeated, the stronger the habit and the greater learning will be achieved. Thus, their listening comprehension in recognition intonation pattern aspect was improved significantly and the hypothesis proposed that by drilling English as a process of habit formation will improve the students listening comprehension better and significantly was accepted.

Besides that, based on the result of observation and interview, the problems the students face in learning micro skills of listening comprehension through drill technique were found. In line with what had been observed during the treatment, the students faced the problems of understanding the difficult words/phrases, recognizing phonetic symbols and intonation pattern; and distinguishing sentence pattern and discourse marker. While listening to the dialogues, the students initially found the difficulty in understanding some words in the dialogues, such as "relief," "choir," "genre," "orchestra," "can't," "stand," "leisure," "arresting," "intending," and "begging." Moreover, the students got confused in recognizing phonetic symbols and intonation pattern of "often," "choir," and "genre." They also found the difficulty in understanding some cohesive devices in the dialogues, such as "therefore" and "furthermore". Besides that, the native speakers sometimes spoke too fast which made the students unable to keep up with the native speaker's speed which made the students felt difficult in comprehending the dialogues.

According to Brown and Yule (1983) in Nunan (1991), there are four factors which can affect the difficulty of listening tasks, such as related to the speaker (how many there are, how quickly they speak and what types of accent they have), the listener (the role of the listener, whether a participant or not, or the individual interest in the subject), the content (grammar, vocabulary, information structure, background knowledge assumed, etc), support 
(whether there are pictures, diagrams or other visual aids to support the text). Based on the result of observation and interview, the problems the students face during the treatment of teaching listening comprehension through drill technique could be divided into: a) Problems from the listener: understanding the difficult words/phrases, recognizing phonetic symbols and intonation pattern, distinguishing sentence pattern and discourse marker, and unable to keep up with the native speaker's speed; b) Problem from listening materials: some dialogues were long.

As in Finocchiaro (1967:55), initially, the students seriously conflict with the production of the new language sounds; thus, the students cannot immediately decode the sounds. According to Flowerdew and Miller (1992:60-80), difficulty in concentration and maintaining concentration for a long time can affect arising the problems from the listener like understanding the difficult words/phrases, recognizing phonetic symbols and intonation pattern, distinguishing sentence pattern and discourse marker, and unable to keep up with the native speaker's speed. Lack of listening practices might lead the students unable to keep up with the native speaker's speed. Besides that, low concentration was another problem that happened in listening process. In line with Flowerdew and Miller (1992:60-80), Underwood (1989:19) stated that inability to concentrate is a major problem because even the shortest break in attention cold seriously impair comprehension. The students' thoughts were generally wandering during speeches and conversations in the dialogues. Thus, the students could not concentrate in understanding the difficult words/phrases by relating it with the topic/content which was being told about to guess what actually the meaning of those difficult words/phrases are. They also could not aware that repetition of some words actually was the signal of main points. When a word or phrase is repeated for several times, it possibly covers the important points to be related to the difficult words/phrases to be guessed. Moreover, they could identify the discourse marker, since discourse marker is considered as the bridge that leads to the topic (Berman, 2000). It is such a natural thing that the speakers often signal the main point thorough discourse markers. Different markers with particular expressions can keep listeners catch up to the turning points of the task. Therefore, the teacher should adjust the students to be more concentrated on the repetition of some words which actually is the signal of main points for comprehending the dialogues, and to be more concentrated on discourse marker, since discourse marker is considered as the bridge that leads to the topic.

Meanwhile, according to Hasan (2000:143), the length of time the students listen may cause memory problems or even fatigue and this will distract their attention from grasping the meaning of the text, and they may miss the rest of the text when there is a lapse in concentration. Therefore, the teacher should provide them with appropriate dialogues and not too long, in order to make them more focused on comprehending the dialogues and train their memory easily.

In conclusion, lack of listening practices and low concentration can lead the students to get confused in understanding the difficult words/phrases and distinguishing sentence pattern and discourse marker, and unable to keep up with the native speaker's speed. Besides that, the long dialogues/texts which lengthen the length of time which causes the memory problems or even fatigue can distract the students' attention from grasping the meaning of the text and the students may miss the rest of the text when there is a lapse in concentration.

Based on the problems above, to minimize the problems and make the teaching-learning activity through drill technique run more effectively, some practical reinforcements are required, such as appropriate teacher, suitable room, and appropriate recording.

a) Appropriate teacher: The teacher should know well about the procedure of teaching listening through drill technique, such as the teacher should master the way of teaching listening comprehension through drill technique, such as mimicry and role-play, and the teacher never uses the native language in the class to attempt the target language effectively. Moreover, since the teacher is the model of the students, an attractive teacher is required to guide and control the students' behavior in the target language.

b) Suitable room: If the listening task is carried out with noises around, it is for sure the students will not have a good result in listening. They will be distracted by the noise no matter how hard they try to focus on listening. Otherwise, the noise makes a complex of sounds instead of the solo recording being played. Therefore, quite surrounding situation is needed in practicing listening comprehension, for an example, the best place for the students to do the listening comprehension practice is in the laboratory room. This somehow will bring out the better result for the noises outside cannot get through the lab room.

c) Appropriate recording: The poor equipment is somehow an obstacle to the students in listening. The recording may be recorded while there are noises around or the cassette is used for such a long time so the quality is worn out. Therefore, appropriate recording is required in practicing listening comprehension. A good recording may give the students more effective listening practice rather than that the old one. 
However, drill technique could overcome those problems. After practicing the dialogues more frequently, the students gradually started to understand the difficult words they encountered before and could practice to spell them correctly and also recognize its phonetic symbols while practicing drilling the dialogues and understanding the intonation pattern effectively through imitation or mimicry toward some words they listened in the dialogues. They also were gradually able to distinguish the difference between sentence pattern and discourse marker, and to comprehend the overall dialogues. Thus, in the last meeting of the treatment, the students felt enjoy practicing listening comprehension through drill technique, since they not only could comprehend the dialogues correctly by memorizing the dialogues they heard which can strengthen the students' memory, but also they could copy the native speaker voice to spell some difficult words correctly, such as "choir," "genre," "presents," etc. Therefore, based on the results above, it can be concluded that drill technique could improve the students' listening comprehension better and significantly, especially in recognizing intonation pattern, and overcame the problems the students face during the treatment of teaching listening comprehension through drill technique.

\section{Conclusion}

After conducting the research in the 1st grade students of SMPN 2 Bandar Lampung and analyzing the data, the conclusions are drawn as follows:

1. There was significant improvement of the students' listening comprehension through drill technique. It was proved by the increase of the students' mean score in the post-test which was higher than in the pre-test. Their post-test score was increased from 52.2 to 78.5, in which the gain was 26.3. Specifically, drill technique improved the students' listening comprehension in all aspects of micro skill types of listening comprehension, such as recognition intonation pattern, recognition sentence pattern, recognition discourse marker, and getting the referential info. Moreover, drill technique mostly improved the students' listening comprehension in recognizing intonation pattern, in which their ability in that aspect was $38 \%$ improved significantly.

2. There were some problems the students face in learning micro skills of listening comprehension through drill technique. First, problems from the listener are related to understanding difficult words/phrases, recognizing phonetic symbols and intonation pattern, distinguishing sentence pattern and discourse marker, and inability to keep up with the native speaker's speed. Second, some dialogues of listening materials were long.

\section{References}

Alexander, L. G. 1967. First Things First: Teacher's Book. London: Longman.

Anggraeni, Purwita. 2007. Audio-lingual Teaching as an Alternative Method in Teaching Speaking an Action Research Given to the First Year Students of SMP Negeri 2 Pemalang. Semarang: Semarang State University Press.

Apriani, Ni Ketut. 2012. Increasing Students' Listening Ability through Completing Dialog Technique at the Second Year Students of SMKN 2 Bandar Lampung. Bandar Lampung: FKIP Lampung University (Unpublished Paper).

Arikunto, Suharsimi. 1998. Prosedur Penelitian: Suatu Pendekatan Praktek. Jakarta: Rineka Cipta.

Berman, A. 2000. Translation and the Trials of the Foreign. L. Venuti (ed).

Brown, A. and Dowling, P. 1998. Doing Research/Reading Research: A Mode of Interrogation for Education. London: The Falmer Press.

Brown, H. D. 1980. Principles of Language Learning and Teaching. New Jersey: Prentice Hall

Brown, James Dean. 1988. Understanding Research in Second Language Learning. Cambridge: Cambridge University Press.

David, Hendrikus. 1996. Teaching Listening Skill through Someone-says Game. Bandar Lampung: FKIP Lampung University (Unpublished Paper).

Down, Lisa J. 2008. Listening Skills Training. (Online). (http://books.google.co.id, cited on March 08 ${ }^{\text {th }}$, 2012).

Finocchiaro, Mary. 1967. English as a Second Language: From Theory to Practice. New York: Regent Publishing Company. 
Fisher, Carol J. and C. Ann Terry. 1980. Children's Language and the Language Arts. New York: McGraw.

Flowerdew, J. \& Miller, L. 1992. Student's Perceptions, Problems and Strategies in Second Language Lecture Comprehension. RELC Journal, Vol. 23, No. 2, pp. 60-80.

Fraenkel, Jack R. and Wallen, Norman E. 1993. How to Design and Evaluate Research in Education. New York: San Francisco State University.

Gay, L. R. 1987. Educational Research. Columbus: Memill Publishing Company.

Griffee, D.T. 1986. Listen and Act: From Simple Actions to Classroom Drama. English Teaching Forum, Vol. 24, No. 2, pp. 18-23.

Gronlund, Norman E. 1982. Constructing Achievement Tests. New Jersey: Prentice Hall.

Harris, P. David. 1969. Testing English as a Second Language. New York: McGraw-Hill.

Hasan, A. S. 2000. Learners' Perceptions of Listening Comprehension Problems. Language, Culture and Curriculum, Vol. 13, No. 2, pp. 137-153.

Heryanto, Erlan. 2011. Improving Students' Speaking Ability through Pattern Drill Technique at the First Year of SMA Sunan Kalijaga, Jati Agung. Bandar Lampung: FKIP Lampung University (Unpublished Paper).

Krashen, S. 1985. The Input Hypothesis. London: Longman

Larsen-Freeman, Diane. 2000. Techniques and Principles in Language Teaching. New York: Oxford University Press.

McIntosh, Lois and Marianne Celce-Murcia. 1979. Teaching English as a Second or Foreign Language. New York: Newbury House.

Nunan. 1991. Language Teaching Methodology. London: Prentice Hall.

Richards, J. C., Plat, J. and Weber, H. 1987. Longman Dictionary of Applied Linguistics. Hong Kong: Longman Group.

Setiyadi, Ag. Bambang. 2006. Metodologi Penelitian untuk Pengajaran Bahasa Asing, Pendekatan Kuantitatif dan Kualitatif. Yogyakarta: Graha Ilmu.

Setiyadi, Ag. Bambang. 2006. Teaching English as a Foreign Language. Yogyakarta: Graha Ilmu.

Underwood. 1989. Teaching Listening. New York: Longman.

Unila. 2011. Format Penulisan Karya Ilmiah. Bandar Lampung: Universitas Lampung.

Valette, Rebecca M. 1983. Modern Language Testing. New York: Harcourt Brace Jovanovich.

Yufrizal, Hery. 2007. An Introduction to Second Language Acquisition. Bandar Lampung: Pustaka Reka Cipta. 